\title{
Utilization of Cyclic Natural Rubber to Modified Asphalt
}

\author{
Winsyahputra Ritonga ${ }^{1}$, Muhammad Aswin Rangkuti ${ }^{2}$, Eddiyanto $^{3}$, Septian Prawijaya ${ }^{4}$ \\ \{ winsyahputra@unimed.ac.id $\left.{ }^{1}\right\}$ \\ Department of Medan State University, Medan, Indonesia ${ }^{1,2,3,4}$
}

\begin{abstract}
This research aimed to determine the stability value of modified asphalt using a cyclic natural rubber. Modified asphalt designed with mixing with the pure bitumen with cyclic natural rubber. The increasing of cyclic natural rubber on a mixture of bitumen started from $0 \mathrm{phr}, 1 \mathrm{phr}, 3 \mathrm{phr}$, and $4 \mathrm{phr}$. Furthermore, modified bitumen (5 samples) tested with testing property requirements test of pure asphalt. The results obtained that the data qualified for property requirements for asphalt. The next step was making a specimen with mixing the modified bitumen, soft aggregate and coarse aggregate to optimum asphalt content of $6 \%$. Then the specimen tested with Marshall Test to determine the value of bitumen stability. Then the result of stability value from sample 1 to 5 was $1252 \mathrm{~kg}, 1129 \mathrm{~kg}, 1159 \mathrm{~kg}, 1312$, and $1320 \mathrm{~kg}$ respectively. Based on the results, the conclusion of this research was cyclic natural rubber could be used as a material to modified asphalt as well as increased the value of asphalt stability. The increasing of stability value meant that highway could hold a heavier load.
\end{abstract}

Keywords: Modified Asphalt, cyclic natural rubber, stability

\section{Introduction}

Seven characteristics mustbe owned asphalt mix: stability, durability or durability, pliability or flexibility, resistance to fatigue (fatigue resistance), surface roughness or shear resistance, waterproof, and easy to implement (Sukirman, 2012). Stability is the ability of pavement receive traffic loads without permanent deformation occurs in waves, grooves, and bleeding. The need for stability comparable to the function of the road and the traffic load will be served. Roads that serve high traffic volume and predominantly consist of heavy vehicles in need of pavement with high stability. Instead of pavement that is intended to serve the light vehicle traffic, would not require the value of stability.

Several factors generally cause damage to the highway. One effect is the activity of mobilization by the transportation of goods and people in the use of the road that sometimes does not comply with the rules could affect the life of roads. The high mobility of road transport activity will affect the stability of the asphalt. Asphalt stability will impact on the durability of asphalt and road damage.

To improve the stability of bitumen, required a strong bond between the asphalt and aggregates. Aggregate is a mixture of market, gravel, crushed stone or other materials derived from natural or artificial materials. Aggregate is a significant component of the structure of the pavement, which is (90-95) \% of aggregate based on the percentage of weight. Thus the 
quality of the road pavement structure is determined by the aggregate nature and results of the aggregate mixture with other materials (Sukirman, 2012).

An asphalt binder (matrix) which brings together all the aggregates in the manufacture of the highway. Bitumenis used as a material in road pavement serves as 1) a binder, providing a strong bond between the asphalt and aggregates and asphalt among others; and 2) a filler, fill the voids between the grains of aggregate in the pores in the grain aggregate itself (Sukirman, 2012). Based on its functions, asphalt has a vital role in the quality of asphalt. Excellent quality of asphalt will potentially improve the quality of roads and vice versa.

Various modifications of asphalt have been made to improve the stability of asphalt. One research showed that the value of stability meets the specifications issued by the highways stability value that was obtained in $1331 \mathrm{~kg}$ which had outweighed the minimum value of $1000 \mathrm{~kg}$ (Wasono, 2013). Another result (Ritonga W, Wiryosentono B, Nasruddin, 2013) showed that the asphalt mixture with natural rubber asphalt cyclic meets the physical requirements required by the Indonesian National Standard (SNI) (Departemen pekerjaan Umum, 2005).

A new material that allows trying to serve in the manufacture of asphalt mix is natural rubber cyclic (cyclic natural rubber). Cyclic natural rubber is one form of natural rubber modified by heating using an acid catalyst. Different cyclic properties of natural rubber with natural rubber origin.Excess cyclic natural rubber which is resistant to rub power and has better adhesion. The primary use is cyclic natural rubber as a raw material for paints, coatings, and adhesives(Chusna, 2002). This study aims to determine the effect on the stability of cyclic natural rubber asphalt. Expected by adding a cyclic natural rubber will increase the stability of asphalt mixture so that the quality of the highway could be better.

\section{Materials And Methods}

This research was conducted at the Laboratory of Civil Engineering PoliteknikNegeri Medan. The instruments used in this study were penetration test, thermometer, timer, soaking tub (water bath), rings (made of brass), steel balls, a heat source (heater), mold brass ductility, ductility testing machine, pycnometer, glass vessels, thermostat, analytical balance, oven, mixer, while the material used is asphalt Pen Cyclic 60-70 and natural cyclic rubber.

The first stage conducted in this study was to test the physical properties of asphalt. Asphalt modified was designed by mixing (60-70) pen bitumen, acrylic acid benzoyl peroxide into the beaker, heated for 30 minutes at a temperature of $90^{\circ} \mathrm{C}$, and $180 \mathrm{rpm}$ until melted. The same treatment was also finalized with the variation of asphalt with cyclic natural rubber shown in Table 1.

Table 1: The composition of Mixed Research Samples

\begin{tabular}{cccccccccc}
\hline Sample & \multicolumn{2}{c}{ Asphalt } & \multicolumn{2}{c}{ CNR } & \multicolumn{2}{c}{$\begin{array}{c}\text { Acrylic } \\
\text { Acid }\end{array}$} & \multicolumn{2}{c}{ BPO } \\
\cline { 2 - 10 } & gr & phr & gr & ph & ml & phr & Gr & Mr \\
& & & & r & & & & 0 & 0 \\
1 & 2000 & 100 & 0 & 0 & 0 & 0 & 0 & 0.05 \\
2 & 2000 & 100 & 20 & 1 & 5 & 0.25 & 0.336 & 0.05 \\
3 & 2000 & 100 & 40 & 2 & 5 & 0.25 & 0.336 & 0.05 \\
4 & 2000 & 100 & 60 & 3 & 5 & 0.25 & 0.336 & 0.05 \\
5 & 2000 & 100 & 80 & 4 & 5 & 0.25 & 0.336 & 0.05 \\
\hline
\end{tabular}


After making modified asphalt, physical properties test was performed to determine the asphalt characteristics by the SNI. Samples testing were carried out in the form of testing the physical properties of bitumen which includes penetration, softening point, ductility, density, impairment/lose weightand penetration afterlosing the weight.

Further testing will be done on the physical properties of aggregates. Aggregates in asphalt highway included coarse and fine aggregates. Testing of asphalt-aggregate properties included moisture absorption, bulk density, effective density, and abrasion. The next step was to manufacture the test object. Making a test specimen made by mixing sand (fine aggregate) and gravel (coarse aggregates) with asphalt modification. The optimum asphalt content used was $6 \%$. Test specimen made as many as five specimens representing each sample of bitumen modification. After the making of the object was completed, the next stage was toMarshalltest to the specimens. This test was performed to determine the value of the characterization of modified asphalt.

\section{$3 \quad$ Results And Discussion}

\subsection{Physical Properties Test}

The first stage of the research was to test the physical properties of the asphalt to the pure asphalt with iran pen 60/70 (sample 1) and modified asphalt (sample 2, 3, 4, and 5). Physical requirements included penetration test, softening test point, ductility tests, density tests, test weight, and the penetration test after the weight of the asphalt that has been modified according to the SNI. Results of testing physical requirements pure asphalt are as shown in Table 2 .

Table 2: The Result of Physical Properties from Different Samples of Modified Asphalt

\begin{tabular}{clccccc}
\hline No & \multicolumn{1}{c}{$\begin{array}{c}\text { Physical } \\
\text { Properties Test }\end{array}$} & \multicolumn{2}{c}{ Sample } & \multicolumn{3}{c}{} \\
\cline { 3 - 7 } & & 1 & 2 & 3 & 4 & 5 \\
\hline 1 & Penetration (mm) & 72.50 & 53.17 & 51.83 & 47.00 & 46.50 \\
2 & Softening point $\left({ }^{\circ} \mathrm{C}\right)$ & 35.00 & 39.50 & 42.00 & 42.50 & 44.50 \\
3 & Ductility (cm) & 110.00 & 120.00 & 150.00 & 150.00 & 150.00 \\
4 & Density of asphalt & 1.01 & 1.02 & 1.02 & 1.03 & 1.09 \\
5 & Losing weight (\%) & 1.00 & 2.15 & 2.32 & 2.34 & 2.40 \\
6 & Penetration after & 70.20 & 50.30 & 49.00 & 47.59 & 45.08 \\
& weight lost (\%) & & & & & \\
7 & Decreased ductility & 55.00 & 60.00 & 75.00 & 75.00 & 75.00 \\
\hline
\end{tabular}


The data showed that the addition of concentration of cyclic natural rubber on asphalt using compatibilizer acrylic acid and benzoyl peroxide gave effect to the physical properties of the asphalt. The addition of natural rubber cyclic was making the lower value of penetration bitumen into 40/50 with a previous 60/70. Due to the penetration value decreased, so that the requirements of the physical properties of the asphalt adjusted to SNI Pen 40/50.

Based on Table 2, the increase of the concentration of cyclic natural rubber in modified asphalt impacted the low value of bitumen penetration. Bitumen penetration is a level of stiffness which is meant the inclusion of needle. The higher the penetration value, the more soft asphalt and vice versa. The addition of cyclic natural rubber in asphalt resulting penetration value became smaller which means the asphalt became stiffer.

The addition of natural rubber concentration of cyclic also increased the value of the softening point of modified asphalt. The increasing of softening point value means the asphalt stiffer and vice versa. The results of properties test of softening point are still in the same condition with the results of the penetration test that showed asphalt became stiffer. Hardening of asphalt was possible because the strengthening of the bond between the asphalt particles resulting cyclic function of natural rubber to glue bonds between the particles. This situation is also by the revelation Palupi NPet al., (2008) which states that the cyclic natural rubber can serve as an adhesive resin in the mix of materials.

Based on the results of testing the physical properties of the asphalt on table 3 above, it can be seen that the concentration of cyclic addition of natural rubber until 4 phr fulfilled the physical properties of asphalt. Thus the cyclic natural rubber can be used as a mixture of asphalt.

\subsection{Stability of Modified Asphalt}

Figure 1 showed that the addition of cyclic natural rubber affected the modified bitumen stability value. The greater the concentration of cyclic natural rubber applied to the asphalt mixture and the aggregate affected the higher the value of asphalt stability. The stability value of sample 1 (pure asphalt) was $1252 \mathrm{~kg}$, while the addition of cyclic $4 \mathrm{phr}$ natural rubber (sample 5) had a stability value of $1320 \mathrm{~kg}$. The overall sample met the standard value of asphalt stability of at least $800 \mathrm{~kg}$. The relationship between the cyclic addition of natural rubber against asphalt modification value stability can be seen in the following figure:

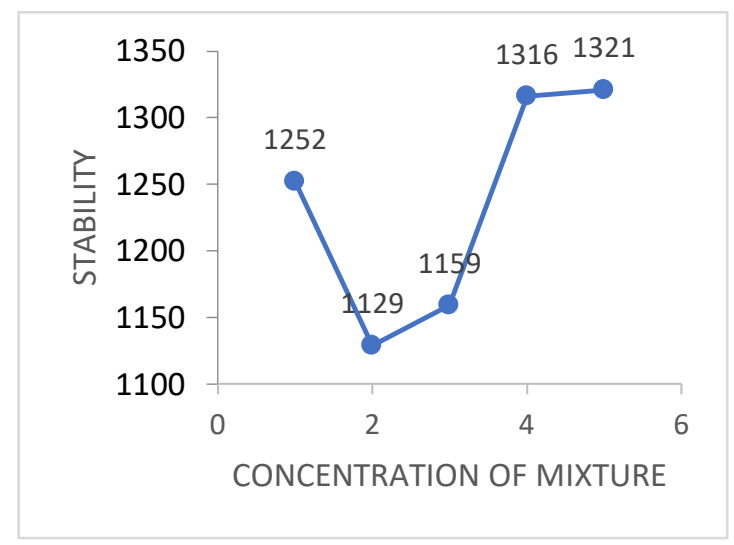


Fig. 1. The relation between the addition of cyclic natural rubber to the value of stability

The research data showed that the addition of cyclic natural rubber concentration causes the value of asphalt stability was greater. Based on modified bitumen standard, the high stability value indicated the asphalt could hold a heavier load. The resistance to load was a form of the strength of asphalt. The increasing of asphalt strength may be caused by cohesion between asphalt and aggregate whose strength is better when cyclic natural rubber is added. The results by Cubuk (2009) also found the addition resins could improve the stability of the asphalt.

\subsection{Density of Asphalt Modified}

The addition of cyclic natural rubber affected the modified bitumen density value (Figure 2 ). The greater concentration of cyclic natural rubber applied to the asphalt mixture,and its aggregate had little effect on the asphalt density. The density value for sample 1 (a pure bit) was 2.41 , while the addition $4 \mathrm{phr}$ of cyclic natural rubber (sample 5) had a stability value of 2.42. The entire samples met the density standard. The relationship between adding cyclic natural rubber to the modified bitumen stability could be seen in Figure 2.

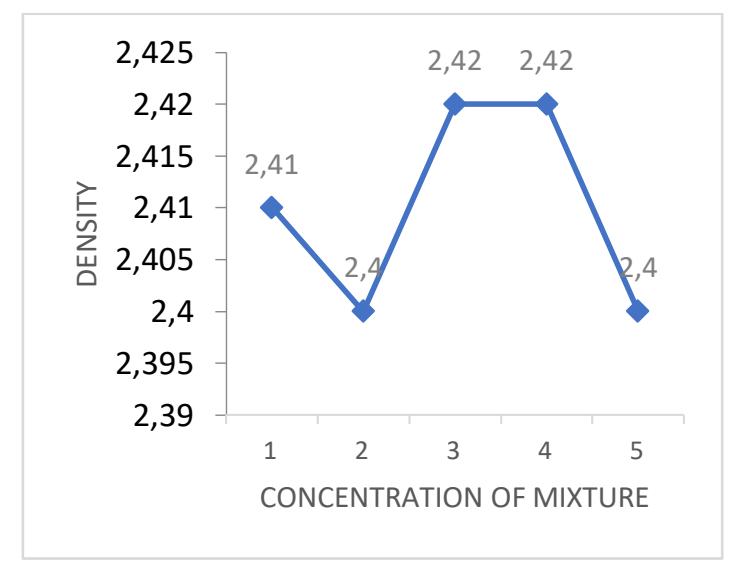

Fig. 2. The relation between the addition of cyclic natural rubber to the value of density

\subsection{Flow of Asphalt Modified}

The relationship between adding cyclic natural rubber to asphalt flow value couldbe seen in Figure 3. Based on the figure, it showed that the addition of cyclic natural rubber effected on the value of asphalt flow. The flow value of pure asphalt was 3.6, while the flow value of modified asphalt (sample 4) was 4.18. 


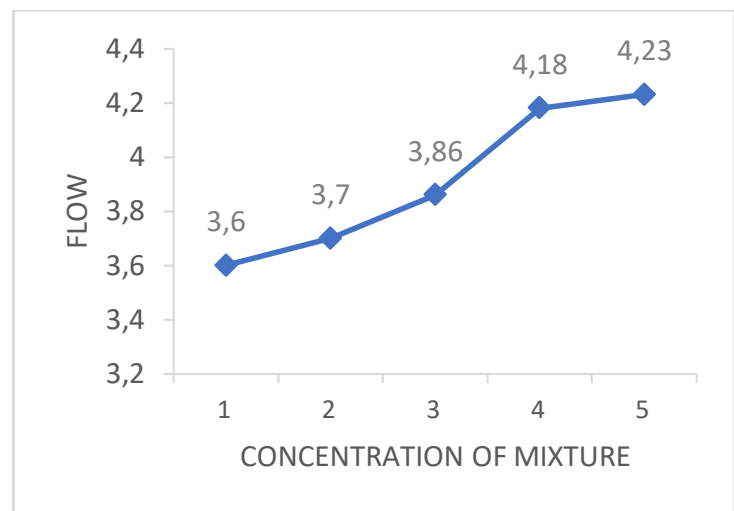

Fig. 3. The relation between the addition of cyclic natural rubber to the value of the flow

The research data showed that the addition of cyclic natural rubber concentration caused the flow value of asphalt was greater. Based on the modified asphalt standard, high-density values indicated the better asphalt is holding the load. The results of this study wereby findings of Sidiq (2013) that kerosineserved as an agent or a wetting agent that will lower the density of the asphalt so that the asphalt becomes more easily detached.

Also, this study was also by the results of research Ritonga (2016) that modified asphalt with palm kernel ash may increase its density value. This is likely due to the composition of the constituents, filler levels, compaction energy, and asphalt content.

\section{Conclusion}

In the quality analysis according to SNI, penetration of iran asphalt with the value of 6070 after modified with cyclic natural rubber is declared feasible to be used.Also, marshall test data showed that the addition of cyclic natural rubber concentration on asphalt affected modified asphalt characterization. This addition increased the stability and density value of asphalt where high values indicated asphalt could hold a heavier load.

Acknowledgments. The researcher would like to extend his gratitudeto the Ministry of Research, Technology and Higher Education for funding this research under the schema of Penelitian Strategis Nasional Institusi 2018.

\section{References}

[1] Chusna SF.: Post Graduate School. (2002). Institut Pertanian Bogor

[2] Cubuk M., Guru M., Cubuk MK.: Fuel.,88. pp. 1324-1328 (2009)

[3] DepartemenPekerjaanUmum.: SpesifikasiUmumBidangJalandanJembatan. (2005). Jakarta

[4] Palupi NP., Sailah I., Syamsu Y., Pandji C.: Vol. 4, pp. 19-24. JurnalTeknologiPertanian (2008)

[5] Ritonga W., Wiryosentono B., Nasruddin.,2013.: Vol. 1. Jurnal Einstein (2013)

[6] Ritonga W., Rangkuti MA., Irfandi.,Ritonga NY.: In National Physics Conference on Yogyakarta State University. (2016) 
[7] Sidiq M., Rachmadani S., Altway A., Nurkhamidah S.: Vol. 2, pp. 1-13. (2013)

[8] Sukirman.: Beton Aspal Campuran Panas. (2002)

[9] Wasono, SB.: Vol. 10, pp. 55-68. Jurnal Neutron (2010) 